\title{
【論文】
}

\section{複数超音波レーダを用いた高齢者行動検知システム \\ Elderly People Behavior Detection System Using Several Ultrasonic Radars}

\author{
田中 幹也(正会員)，吉武 昇太(非会員)，中島 翔太(正会員) \\ 春山 和男(正会員)*，若佐 裕治(非会員)
}

Kanya Tanaka, Shota Yoshitake, Shota Nakashima

Kazuo Haruyama*, and Yuji Wakasa

\begin{abstract}
In recent years, the population of elderly people is increasing rapidly. The shortage of workers who take care of them is becoming serious. Based on these situations, the burden of the care workers has become a big social problem. Therefore reducing the care workers burden is important. In this paper, we propose the novel behavior detection system using several ultrasonic radars. In the system, a new decoupling method, in which the transmitting time periods of ultrasonic wave is altered, is introduced into the ultrasonic radars. The effectiveness of the method was confirmed by the field tests with a healthy male in 20 experiments. However, further field tests with elderly persons in actual living facilities are necessary to verify the usefulness of the system for them. This system can be useful for safety management for the elderly people, and reduce the work of a care worker.
\end{abstract}

\section{Key Words}

Ultrasonic Radar, Decoupling, Elderly People

\section{1. はじめに}

2011 年 3 月 1 日現在, 日本の 65 歳以上の高齢者人口は 2962 万人に達し, これは総人口の $23.2 \%$ 占めている. つまり, 約 4 人に 1 人は高齢者という超高齢社会に突入しつつある. また, 人口の高齢化に伴い認知症患者も増加しており大きな社会問題 となっている. 一方, 高齢者数の増加に対して介護者数が圧倒的 に不足しており, 高齢者の介護施設や高齢者を抱える家庭では

\footnotetext{
2012 年 6 月 20 日受理

2012 年 11 月 18 日最終原稿受理

山口大学大学院理工学研究科

山口県宇部市常盤台 2-16-1

*宇部工業高等専門学校

山口県宇部市常盤台 2-14-1

Graduate school of Science and Engineering, Yamaguchi University,

2-16-1 Tokiwadai, Ube, Yamaguchi, Japan

*Ube National College of Technology

2-14-1 Tokiwadai, Ube, Yamaguchi, Japan
}

介護者に過度の負担がかかり，この問題の解決が急務となって いる.このため介護現場で介護者を支援するための様々な装置 やシステムが研究開発されている 1) 4). 筆者らもマットセンサと電 灯線通信を用いた離床検知システムを提案している5)。これは高 齢者がベッドから勝手に離れて徘䧃寸ることを防止するために, ベッド横の床上に感圧式のマットを置き, この上に高齢者が降り 立つと圧力を検知して, 電灯線通信を使用して別室の介護者に 通報するシステムである. しかし，マットを敷いた際にマットの厚さ で床との僅かな段差が生じ, 歩行が不自由な高齢者は躓いて転 倒してしまうといら危険性がある. また, マットを踏みつけて使用す るために断線して故障してしまうことも多い. その他にも, 高齢者 がマットに違和感をもち故意にマットを避けるため離床を検知でき ない等の問題が生じた. これらの問題を解決するため, 筆者らは 超音波センサを用いて離床を検知する超音波レーダ (Ultrasonic Radar : USR)を開発した. 赤外線センサを用いた 在宅行動システムもあるが 6), 太陽光が直接入射する空際などの 場所では動作しない恐れがあるので超音波を選択した. USR は カメラを用いないため高齢者のプライバシーを侵害せず, システ ムも簡単で安価であるという特徵をもつ.この USR の有用性は, 
特別養護老人施設で実施したフィールド試験により検証されてい る7). しかしこの USR は単独での使用を前提にしているため, 同 装置を複数台同時使用した場合には同一周波数の超音波が干 渉を起こし正常な機能を発揮できないという問題点があった. 周 波数の異なる超音波センサを採用すれば干渉は避けることがで きるが, 各センサに適合した個別の回路設計が必要になり, 価格 も高くなり, 各センサの有効計測距離が異なるなど種々の問題が ある. 複数の超音波センサを使用した行動検知システムがあるが 8),9) , 非干渉化の手法は提案されていない. この問題を解決する ために筆者らは同一周波数の超音波センサの送信信号デューテ イ比を変更する方法を用いた離床検知システムを提案した ${ }^{10), 11)}$. しかし, 送信信号デューティ比を決めるためには事前に予備実験 をしてデータを収集分析して決める必要があり, そのようにして決 めた送信信号デューティ比も現場が異なれば適用できないことが 多かった. 現場毎にベッド周りに様々なものが配置されており環 境が異なるため, 障害物を避けるようにレーダを設置し, 設置後 に適したデューティ比を決める必要がありケースバイケースで対 応していた. このため本論文では, 複数台の USR の送信超音波 の送信信号幅を異なったものに設定する簡易な非干渉化の方法 を提案する. また，実際の介護現場では離床検知ばかりでなく高 齢者の部屋内の移動や部屋からの退室などの状況も把握する必 要がある. 本論文では, 介護士が高齢者の居室外にいるときに高 齢者の室内での行動を検知するシステムを, 非干涉化 USR を用 いて提案し, 高齢者の居室内での行動を把握するために実施し たフィールド試験の結果を示す.

本論文の構成は以下の通りである. まず第 2 章で USR システ ムについて述べ, 第 3 章で提案する非干渉化の手法について説 明する. 最後に第 4 章で提案手法の有用性を確認するために行 ったフィールド試験について述べる.

\section{1 システム構成}

\section{2. 超音波レーダシステム}

本システムは, 超音波の送信, 受信を行い, 取得した受信信 号をもとに, レーダから高齢者までの距離を測定することによって, 高齢者の起床・離床, 居室内の移動, 退室などの行動を検知す るためのシステムである. 本システムは超音波送信センサ 1 個, 超音波受信センサ 1 個, マイクロコントローラ(Microchip, PIC16F873A)を搭載した信号処理回路から構成する. Fig.1 に USR の外観を示す. USR の大きさは $0.070 \times 0.125 \times 0.040 \mathrm{~m}$, 超音波センサ間の距離 $\mathrm{d}=0.095 \mathrm{~m}$ となっている. また上部の空か ら 7segLED に表示される測定した距離を確認ができ, またスイッ チボタンを操作することによって USR の設定を変更することが可 能となっている.

\section{2 超音波による距離測定と検知判定}

Fig.2 UUSR のブロック図を示す. USRの距離測定の方法は, 送信信号しして $40 \mathrm{kHz}$ の矩形波をマイクロコントローラで生成し, 超音波トランスミッターに電圧を印加寸ることによって超音波を送 信している. 送信信号停止後に $93.5 \mathrm{~ms}$ の受信時間を設けており, この間に対象物によって反射した超音波を超音波レシーバーが
受信し, オペアンプで増幅を行い, 検波積分してからマイクロコン トローラに入力している. この送信信号を生成してからマイクロコ ントローラに受信信号が入力されるまでの時間を計測することに より, 対象物までの距離を求め, 計測した距離を 7segLED に表 示する. このとき, Fig.2 に示すように, 旅密には超音波の伝搬速 度を温度補正することと反射角 $\theta$ とを考慮する必要があるが, 本 システムの使用目的を満たす精度から，超音波の伝搬速度 $\mathrm{V}=340 \mathrm{~m} / \mathrm{s}$, 反射角 $\theta \doteqdot 0$ として計算を行っている.

また, 高齢者の行動を判定するために USR が常に一定の距 離を計測するように適切に配置する. 各レーダの計測有効範囲 内に高齢者が入れば計測距離が変化するため行動を判定するこ とが可能になる. 例えばベッドの頭側に USR 1 を常に壁までの一 定距離を計測するように設置しておく. 高齢者がベッド上で体を 起こす行動を行ったとき, USR1の計測距離が壁から高齢者に切 り替わり, 高齢者の起床が検知できる. USR2 をベッド下に設置し た場合は前述の計測により離床を検知できる. また, ドアの横に USR3 を設置すれば, 部屋からの入退室を検知できる. 複数の USR の計測結果から高齢者の室内での行動を詳細に知ることが できる. したがって, 本システムで高齢者の行動を正確に把握す るためには, USRをどのように配置するか事前に十分検討してお くことが重要である.

\section{3 超音波センサ}

本システムで使用した超音波センサは日本セラミック社製の空 中用開口型超音波センサで, 送信用素子 T40-16 と受信用素子 R40-16 のペアになっている. 素子の大きさは $\phi 0.0162 \times$ $0.0122 \mathrm{~m}$ の円筒形で中心周波数は $40 \mathrm{kHz}$, 半減全角は $50^{\circ}$ で 非常に感度が高いといら特徴がある。

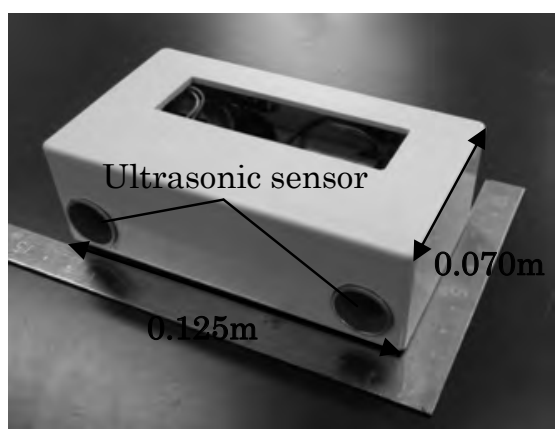

Fig. 1 Ultrasonic radar.

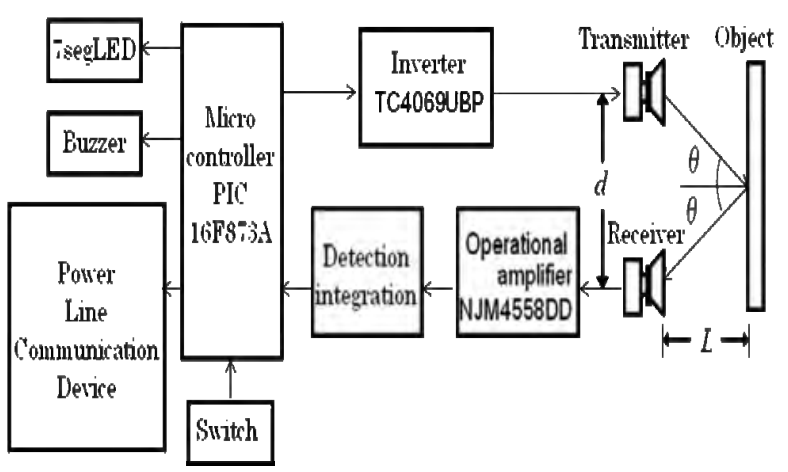

Fig. 2 Ultrasonic radar block diagram. 


\section{3. 超音波レーダの非干渉化}

\section{1 超音波の干涉}

文献 7)に示寸ように, 中心周波数 $40 \mathrm{kHz}$ の超音波センサを 用いた USR を単独で使用する場合には対象物までの正確な距 離計測が可能である. しかしこのような USR を送信信号が混在 する範囲内で複数台同時に使用寸ると, 各 USR の受信センサは 他の USR から発信された超音波や対象物で反射した超音波を 受信し，本来自身が発信した超音波の反射波と区別できなくなる 干渉が起こる. このとき, USR は受信した第一波までの距離を計 測してしまい, 本来の距離よりも短い計測を行うため, 正確な距離 測定が不可能となる.

\section{2 超音波の非干渉化}

Fig.3 に超音波トランスミッターからの送信信号と超音波レシー バーの受信信号のオシロスコープ映像を示している. Fig.3(a)は, 上段に $40 \mathrm{kHz}$ の超音波を連続して $250 \mu \mathrm{s}$ 発信する信号幅

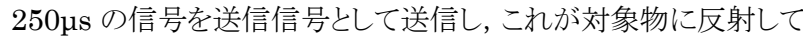
受信した信号を下段に示している. Fig.3(b)は，上段に信号幅 2000Hs の超音波を送信し，その場合の受信信号を下段に示し ている.これらの図から, 送信信号幅が大きくなれば, 受信信号 幅もそれに応じて大きくなっており識別は容易であることが解る. これより各USRで異なる送信信号幅を割り当てれば, それに応じ た自機の受信信号幅を識別できるので, 複数の USR を用いても 非干渉化が実現できると考えられる.

このためUSRから $1.0 \mathrm{~m}$ の距離に人を立たせて様々な送信信 号幅を変えて超音波信号を送信し, 受信した反射波の信号幅を 計測した結果を Table.1 に示寸。信号幅の計測は, オシロスコ 一プを用いて $3.53 \mathrm{~V}$ 以上の部分の信号幅の計測を行った.この 表を用いれば同時に 7 台の USR の非干渉化が可能である. 受 信信号幅が送信信号幅より長くなったのは, 超音波トランスミッタ 一が $40 \mathrm{kHz}$ の駆動信号が無くなった後も内部の振動板が振動し 続け超音波を送信してしまうことや、超音波が伝搬する間に空気 の密度や温度の影響を受けるのが原因だと考えられる。

提案手法の検知プロセスのフローチャートを Fig.4 に示す. 対 象物を検知するプロセスは, 送信プロセス, 受信及び受信時間幅 測定プロセス, 距離測定及び検知判定プロセスから成っている. 送信プロセスでは, 各USRについて予め設定した時間幅の矩形 波を生成し, 超音波トランスミッターに印加することで超音波を送 信する. 受信及び受信時間幅測定プロセスでは, 対象物に反射 してきた受信信号のノイズ処理を行う.ノイズと超音波との区別は 受信した信号が設定された閾值を超えているかどうかで区別を行 う. 閾值を超えている場合は, 超音波とみなして受信時間幅の測 定に移る. 受信時間幅は, 連続で閾値を超えている信号部分の 時間幅を測定することによって求め, 自機の発信した信号に対応 した受信信号と一致するか判定する。このとき, 幅の広い超音波 が幅の狭い超音波をマスクすることは理論的には起こりえるが生 起確率は極めて低く, 実用上は全く問題ない. 信号が一致した場 合, 距離測定及び検知判定プロセスに入る. 最初に閾值を超え る信号を受信した時間を用いて距離を求め, 検知判定を行う. 検 知判定は, 予め設定された距離の範囲内に入っているかどうかを

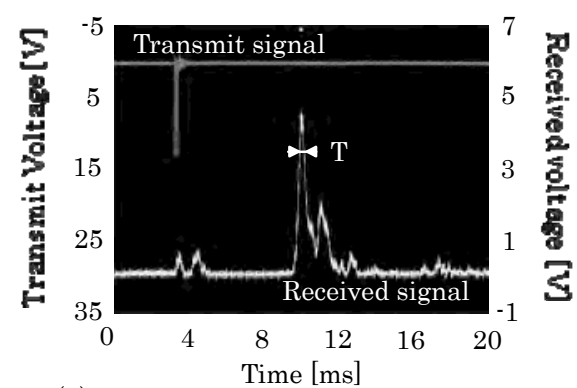

(a) In the case of short transmit time.

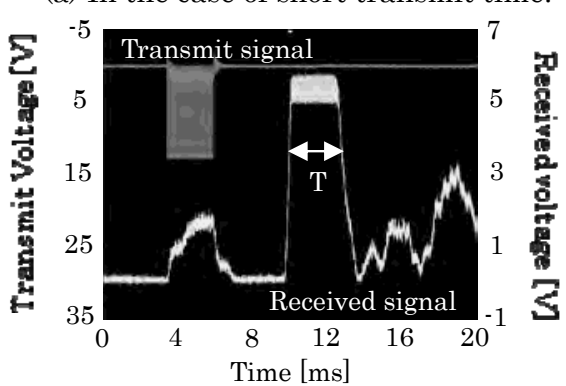

(b) In the case of long transmit time. Fig. 3 Special characteristic of transmit signal and received signal.

Table.1 The relation between transmit time and reception time.

\begin{tabular}{|r|r|}
\hline Transmit time $[\mu \mathrm{s}]$ & Reception time $[\mu \mathrm{s}]$ \\
\hline 250 & 360 \\
\hline 500 & 440 \\
\hline 1000 & 1000 \\
\hline 1250 & 1440 \\
\hline 1500 & 1960 \\
\hline 2000 & 2440 \\
\hline 2500 & 2760 \\
\hline
\end{tabular}

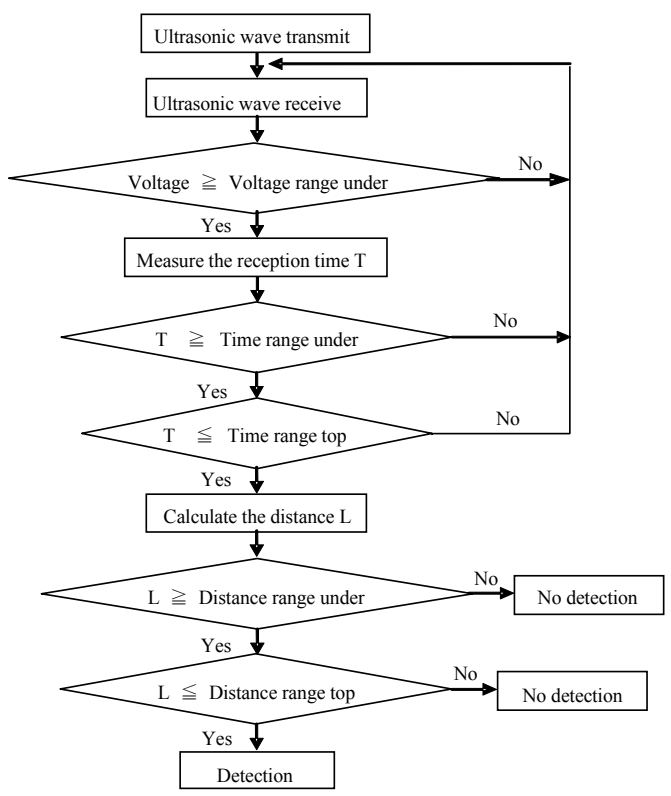

Fig. 4 Flowchart of detection process. 
判定し, 入っている場合に検知したとみなす. 通報システムは, USR に接続された電灯線通信装置を通して管理室にある PC に 計測データが常時送信され，高齢者の行動をモニタリングできる システムとなっている.

\section{4. フィールド試験}

\section{1 相部屋を想定したフィールド試験}

提案手法の有用性を確認するためにベッドが 2 つ向かい合っ て設置された相部屋でのフィールド試験を行った. 被験者は 20 歳代の男性 1 名であるが, 事前にフィールド試験の目的, 内容, 身体への影響(皆無)について説明し了解を得た上で実施した。

Fig.5 に示寸ように各ベッドの頭側に従来型 (非干渉化していな い) USR と非干渉化を行った 2 台の USR を配置した. ベッドマッ トが床から $0.4 \mathrm{~m}$ の高さなので USR は寝返りを検知しないように 床から高さ $0.9 \mathrm{~m}$ のベッド中央に設置した. USR 1,2 は被験者の ベッド上で体を起こす起床を検知することを目的とする. USR 間 の距離は $5.0 \mathrm{~m}$ である. 各 USR は被験者がいないときは壁まで の距離を計測するように設置する. USR は検知範囲 $0.3 \sim 1.2 \mathrm{~m}$ と 設定されており,この設定範囲内の距離を計測すると行動を検知 したと判断する. Table.2 に時間経過中の被験者の行動を示す. 被験者は USR1 側のベッドに横臥した状態から起床し, ベッドの 横に降り立ち離床する, その後部屋を移動してドアから退室する 行動を行った.

Fig.6(a)に従来型を用いた場合のUSR1の試験結果を示す. 図の横軸は時間, 縦軸は計測距離を示している. 従来型では非 干渉化ができていないため自機の超音波受信信号とUSR2 から の信号を区別できず, 壁より短い距離を計測することが多発した. そのため被験者が体を起こしていない場合でも体を起こしている 時と同様の距離を計測し，行動を判定することができなかった. ま たUSR1 の誤動作率は 34.1\%であった.

次に提案した非干渉化をした 2 台のUSRを同じ位置に配置し た. 各USRの超音波の送信信号幅と受信信号幅は次のように設 定した.

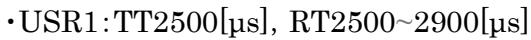

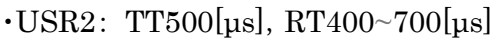

ただし, TT:transmit time, RT:reception time

被験者が同様の行動をした場合の試験結果を Fig.6(b)に示 す. Fig.6(b)から，0sec 20sec 及び 20sec 40sec 以降は計測距 離 $5.0 \mathrm{~m}$ で壁までの距離を計測しているが, $20 \mathrm{sec} \sim 40 \mathrm{sec}$ では $0.8 \mathrm{~m}$ の距離を計測している. 従って, 被験者が $20 \mathrm{sec} \sim 40 \mathrm{sec} に$ 起床の行動を行ったことが予測でき実行動と一致している. USR2 の計測結果は設定した検知範囲の距離を計測することは なく, 被験者の行動を検出しなかった.

また被験者が USR2 側のベッドで同様の行動を行っても USR1 側のベッドで行ったものと同じ結果が得られた. 非干渉化 をすることによって被験者の行動を検知することができ, 非干渉 化の有用性が確認できた.

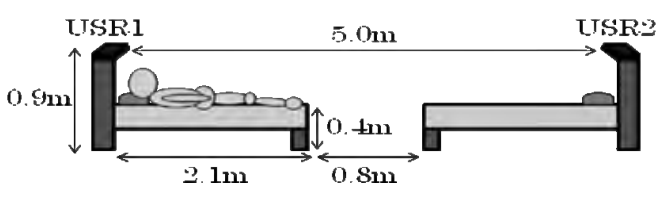

Fig.5 The position of ultrasonic radars at shared room.

Table.2 Behavior of the subject

\begin{tabular}{|c|c|}
\hline Time [m:s] & Behavior \\
\hline $00: 00 \sim 00: 20$ & Lying in bed \\
\hline $00: 20 \sim 00: 40$ & Raise the body \\
\hline $00: 40 \sim 01: 00$ & Get a foot on the floor and stand up \\
\hline $01: 00 \sim 01: 20$ & Move to the door \\
\hline
\end{tabular}

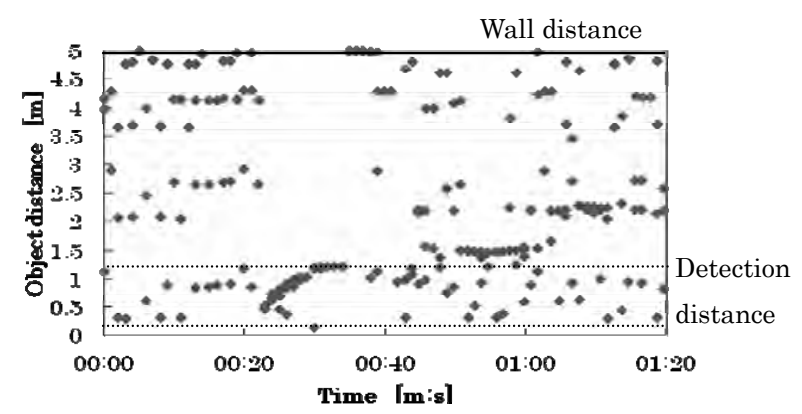

(a) No Decoupling.

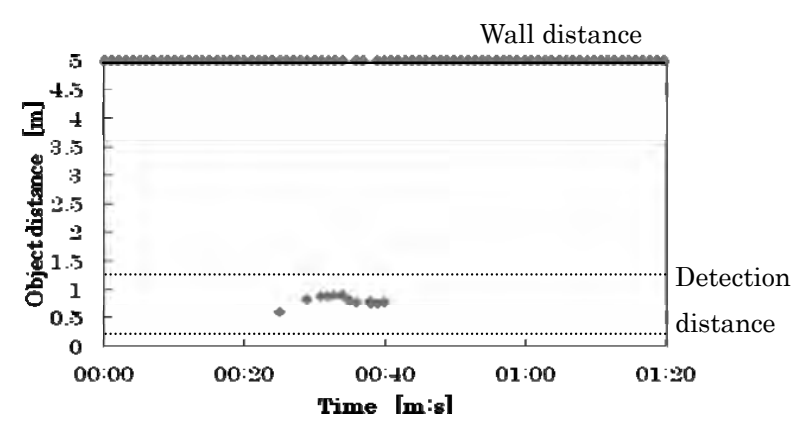

(b) Decoupling.

Fig. 6 Object distance of USR at shared room.

\section{2 個室を想定したフィールド試験}

提案手法の有用性を確認するために個室での行動を検知する フィールド試験を行った. 被験者は 20 歳代の男性 1 名であるが, 事前にフィールド試験の目的, 内容, 身体への影響(皆無)につ いて説明し了解を得た上で実施した. Fig.7 に示すように部屋内 に従来型(非干渉化していない) USR と非干渉化を行った USR をそれぞれ 3 台配置した。 この配置は家族や介護士の方が高齢 者の居室外にいる場合に, 高齢者が危険な行動をとらないか見 守るためである. ベッドマットの高さが床から $0.4 \mathrm{~m}$ なので USR 1 


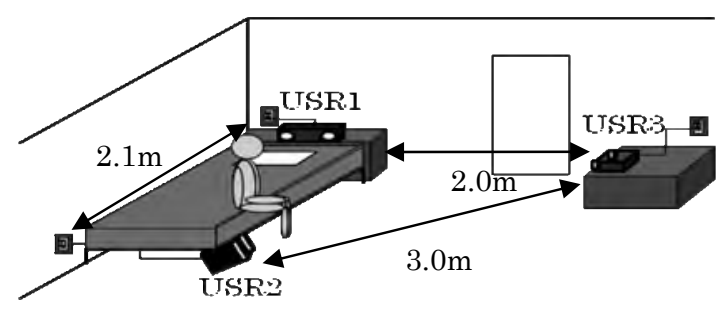

Fig. 7 The position of ultrasonic radars at private room.

は寝返りを検知しないように床から高さ $0.9 \mathrm{~m}$ のベッド頭側中央に USR1 を配置した. USR1 は, 被験者の起床を検知することを目 的とする. USR 1 と壁までの距離は $2.1 \mathrm{~m}$ である. USR2 はスリッ パを検知しないように高さ $0.12 \mathrm{~m}$, 地面から $30^{\circ}$ の角度をつけた 台にのせ, ベッドから $30^{\circ}$ の角度で配置した. USR2 は, 被験者 が離床のため床に足をつく行動を検知することを目的とし, USR2 と壁までの距離は $3.0 \mathrm{~m}$ である. USR3 はドアの横に高さ $0.8 \mathrm{~m}$ の位置に配置し, 被験者がドアから退室する行動を検知す ることを目的とし, USR3 と壁までの距離は $2.0 \mathrm{~m}$ である. 各 USR は被験者がいない場合には USR から壁までの距離を計測して いる. USR は検知範囲 $0.3 \sim 1.2 \mathrm{~m}$ と設定されており,この設定 範囲内の距離を計測すると行動を検知したと判断する.

Table.3 に時間経過中の被験者の行動を示す. 被験者はベッ ドに横臥した状態から起床し, ベッドの横に降り立ち離床する, そ の後部屋を移動してドアから退室する行動を行った.

Fig.8に従来型USRを用いた場合の試験結果を示した. 図の 横軸は時間, 縦軸に計測距離を示している. USR1, USR2, USR3のいずれについても同一時刻に複数の異なる距離計測結 果が示されている. これは従来型 USR では非干渉化ができてい ないため各USR は自機からの超音波受信信号と他のUSRの超 音波受信信号が区別できず合わせて表示しているためである.こ れらの計測結果から被験者の正確な行動判定は困難である. 例 えば Fig.8(a)から受信信号の集中している箇所だけに注目する と, 被験者は $20 \mathrm{sec} \sim 30 \mathrm{sec}, 35 \mathrm{sec} \sim 45 \mathrm{sec}$ の 2 回起床行動をして いるように判断できる. しかし, 実際には $15 \mathrm{sec}$ 30secに 1 回しか 起床行動はしておらず, 誤判断を生じていることになる.このよう に非干渉化ができていない従来型 USR を複数台用いた場合に は被験者の行動を判定できないことが解った. 各 USR の誤動作 率は, USR 1 が $39.6 \%$, USR 2 が $9.8 \%$, USR3が $27.9 \%$ だった。

つぎに提案した方法で非干渉化をした USR3 台を同じ位置に 配置した. 各 USR の超音波の送信信号幅と受信信号幅は Table. 1よりそれぞれつぎのように設定した.

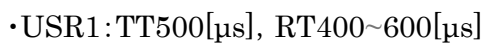

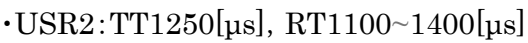

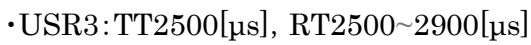
ただし, TT:transmit time, RT:reception time 被験者が同様の行動をした場合の試験結果をFig.9に示した. ま ず, Fig.9(a)から, 0sec 15sec および 30sec 以降は, 計測距離 は $2.1 \mathrm{~m}$ でUSR1 から壁までの距離が表示されているが,
Table.3 Behavior of the subject

\begin{tabular}{|c|c|}
\hline Time [m:s] & Behavior \\
\hline $00: 00 \sim 00: 15$ & Lying in bed \\
\hline $00: 15 \sim 00: 30$ & Raise the body \\
\hline $00: 30 \sim 00: 45$ & Get a foot on the floor and stand up \\
\hline $00: 45 \sim 01: 00$ & Move to the door \\
\hline $01: 00 \sim 01: 15$ & Walk out of the room \\
\hline
\end{tabular}

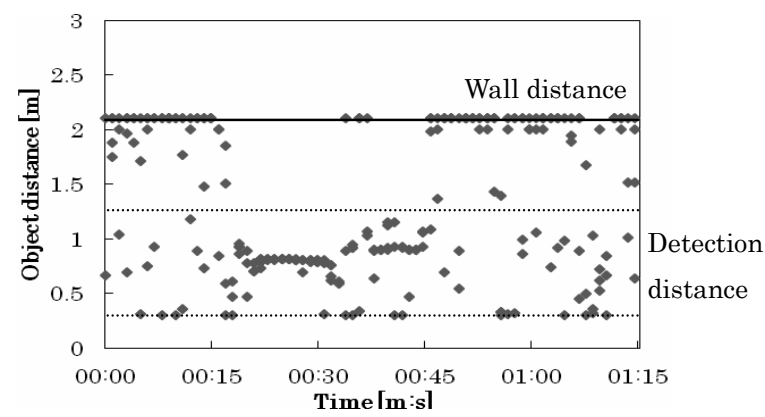

(a) USR1

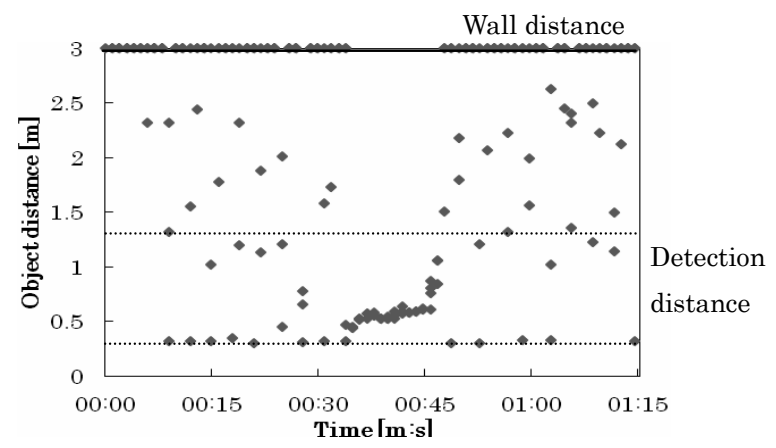

(b) USR2

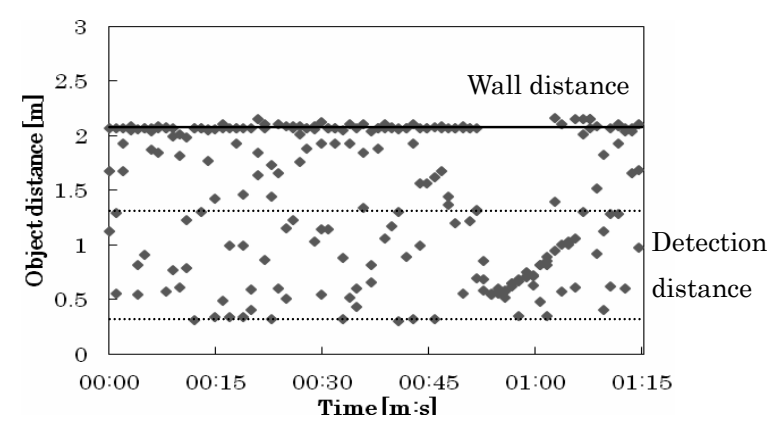

(c) USR3

Fig. 8 Object distance of No Decoupling USR

$15 \mathrm{sec} 30 \mathrm{sec}$ に計測距離が $0.8 \mathrm{~m}$ になっている. したがって被験 者は $15 \mathrm{sec}$ 30sec の間ベッド上に起床したと予測できる.つぎに Fig.9(b)から, 0sec 30sec および 45sec 以降は, 計測距離は $3.0 \mathrm{~m}$ で USR2 から壁までの距離が表示されているが, $30 \mathrm{sec} 45 \mathrm{sec}$ に計測距離が $0.4 \mathrm{~m}$ になっている. これより被験者 は 30sec $45 \mathrm{sec}$ 間に床に足をついたと予測される. また, (a)と(b) 


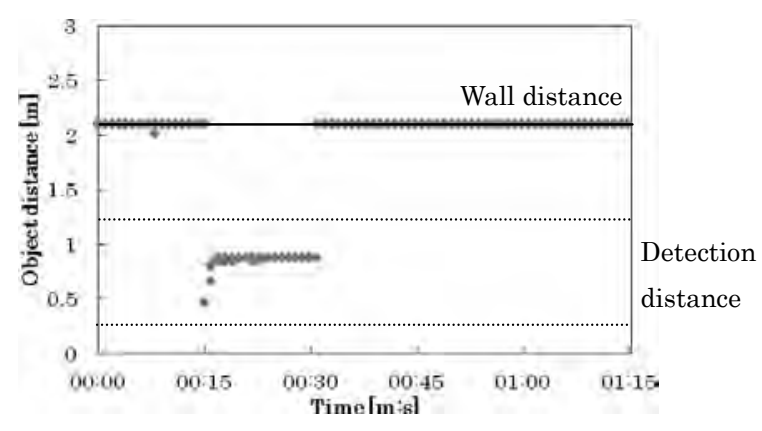

(a) USR1

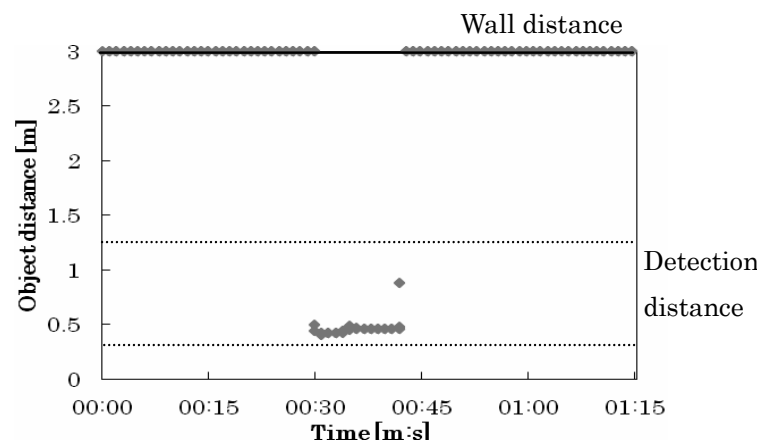

(b) USR2

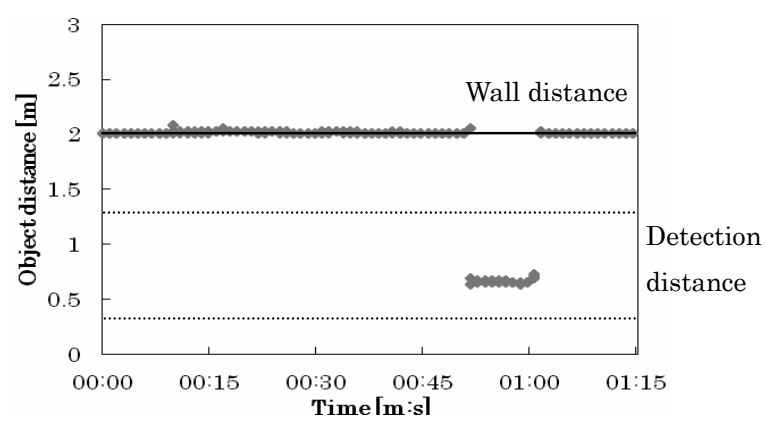

(c) USR3

Fig. 9 Object distance of Decoupling USR

の結果から, 被験者はベッド上に起床し, 離床したと予測される. つぎに Fig.9(c)から, 0sec 45sec および 60sec 以降は, 計測距 離は $2.0 \mathrm{~m}$ で USR3 から壁までの距離が表示されているが, $45 \mathrm{sec} \sim 60 \mathrm{sec}$ に計測距離が $0.5 \mathrm{~m}$ になっている. これより被験者 は 45sec 60sec 間にドアを通過したと予測される. また, (b)と(c) の結果から, 被験者はベッドから離床し, ドアまで移動して退室し たと予測される. 以上の予測は被験者の実行動と一致している. 10 回試行したが, 10 回全てにおいて被験者の行動を検知するこ とができた. 以上の試験結果から非干渉化した USR を複数台使 用することにより被験者の一連の行動を把握できることが解った. また, 提案した USR の非干渉化の方法の有用性が確認できた.

\section{5. まとめ}

本論文では, 複数台の USR を用いた高齢者の行動検知シス
テムを提案した. 複数の USR を同時に使用するために簡易な非 干渉化手法を示し, その有用性をフィールド試験で検証した. 今 後の課題としては，高齢者を被験者とした実験や高齢者が居住 する施設などでのフィールド試験を行っていかなければならない. また，通報システムについても検討し，高齢者の状態が一目でわ かり,介護士が使いやすいシステムの構築を目指したいと考える。 今後とも我が国の高齢者人口は増加しつづけ, 超高齢社会を迎 えることになる. 一方で介護者の不足も慢性的な状況で介護者の 負担は益々重くなることが予想される.このため本論文で提案し た高齢者の行動検知システムが, 介護者の負担の軽減の一助に なれば幸いである。

\section{参考文献}

1）古川聡, 松田啓史, 萩尾健一, 谷口良, 筒井譲二, 田中智幸, ケアモニタ向けセンサの検知技術. 松下電工技報 2001； Feb:16-22.

2）川崎重工業，介護支援システム．産業機械 2001;611： 63-65.

3）古川聡，画像処理技術による高齢者介護用振る舞い検知シ ステム. 電子情報通信学会誌 $2002 ; 85(4): 282-284$.

4）米沢良治, 宮本泰彰, 小川英邦, 槙弘倫, 二宮石雄, 佐田孝 治, 浜田真悟, 病院, 福祉施設における新しい患者行動モ二 タリングシステム. 医科機器学 2002;72(9):429-434.

5) K. Tanaka, K. Haruyama and Y. Yamada, Safety Confirmation System Using Mat-Sensor and Power Line Communications for Elderly Person. Journal of Robotics and Mechatronics 2007;19(6):676-682.

6）品川佳満, 岸本俊夫, 太田 茂, 季節変動に着目した独居高 齢者の在宅行動データの解析．川崎医療福祉学会誌 2006 ;16(1): 121-128.

7）田中幹也, 春山和男, 山田陽, 若佐裕治, 明石卓也, 超音波 レーダと電灯線通信を用いた高齢者用移動確認システム. IT ヘルスケア誌 2008;2(2):95-103.

8）清水雅年, 尾崎史恵, 浜善博, 西村三千雄, 超音波アレイセ ンサを用いた離床検知システムの開発(part1), ライフサポー 卜, 2008, 20(1), 17-22.

9）田嶋拓也, 阿部武彦, 南保英孝, 木村春彦, 超音波センサを 用いた顧客振舞い認知システムの開発〜IT 活用による小売 業売場生産性向上を目指した購買行動計測の基礎実験〜, 知能と情報, 2008;20(2):201-210.

10）春山和男, 山田 陽, 田中幹也, 若佐裕治, 西村悠樹, 送信 信号デューティ比変更法による超音波レーダ型離床検知装 置の非干渉化, 第 7 回生活支援工学系学会連合大会講演 予稿集. 2009;191-192.

11）山田陽，田中幹也, 春山和男, 若佐裕治, 明石卓也, 送信 信号デューティ比変更法による超音波レーダ型離床検知装 置の非干渉化. 電気学会論文誌 D 2010;130(5)： 599-604. 